\title{
Development of a recombinase-aided amplification assay for rapid detection of human norovirus Gll.4
}

Zhiwei Qin ${ }^{1,2}$, Liang Xue ${ }^{1 *} \mathbb{D}$, Weicheng Cai ${ }^{1}$, Junshan Gao ${ }^{1}$, Yueting Jiang ${ }^{3}$, Jiale Yang ${ }^{1}$, Yanhui Liang ${ }^{1}$, Linping Wang ${ }^{1}$, Jumei Zhang ${ }^{1}$ Y Yongdan $\mathrm{Hu}^{2^{*}}$ and Qingping $\mathrm{Wu}^{1 *}$

\begin{abstract}
Background: Human noroviruses are one of the main causes of foodborne illnesses and represent a serious public health concern. Rapid and sensitive assays for human norovirus detection are undoubtedly necessary for clinical diagnosis, especially in regions without more sophisticated equipment.

Method: The rapid reverse transcription recombinase-aided amplification (RT-RAA) is a fast, robust and isothermal nucleic acid detection method based on enzyme reaction. This method can complete the sample detection at $39^{\circ} \mathrm{C}$ in $30 \mathrm{~min}$. In this study, we successfully established a rapid reverse transcription recombinase-aided amplification (RT-RAA) assay for the detection of human norovirus Gll.4 and applied this assay to clinical samples, as well as comparison with commercial reverse transcription real-time fluorescence quantitative PCR (RT-qPCR).

Results: At 95\% probability, the detection sensitivity of RT-RAA was $3.425 \log 10$ genomic copies (LGC)/reaction. Moreover, no cross-reaction was observed with other norovirus genogroups and other common foodborne viruses. Stool samples were examined by RT-RAA and reverse transcription quantitative real-time polymerase chain reaction (RT-qPCR). Compared of RT-qPCR, kappa values for human norovirus detection with RT-RAA were $0.894(p<0.001)$, indicating that both assays were in agreement.
\end{abstract}

Conclusion: This RT-RAA assay provides a rapid, specific, and sensitive assay for human norovirus detection and is suitable for clinical testing.

Keywords: Norovirus, Detection, Rapid diagnostic technique, Recombinase-aided amplification

\footnotetext{
*Correspondence: xueliang@gdim.cn; kunlan881221@126.com; wuqp203@163.com

'Guangdong Provincial Key Laboratory of Microbial Culture Collection and Application, State Key Laboratory of Applied Microbiology Southern China, Institute of Microbiology, Guangdong Academy of Sciences, No. 100, Xianlie Zhong Road, Guangzhou, Guangdong 510070, People's Republic of China

${ }^{2}$ Faculty Agriculture and Food, Kunming University of Science and Technology, Kunming 650500, Yunnan, China

Full list of author information is available at the end of the article
}

(C) The Author(s). 2021 Open Access This article is licensed under a Creative Commons Attribution 4.0 International License, which permits use, sharing, adaptation, distribution and reproduction in any medium or format, as long as you give appropriate credit to the original author(s) and the source, provide a link to the Creative Commons licence, and indicate if changes were made. The images or other third party material in this article are included in the article's Creative Commons licence, unless indicated otherwise in a credit line to the material. If material is not included in the article's Creative Commons licence and your intended use is not permitted by statutory regulation or exceeds the permitted use, you will need to obtain permission directly from the copyright holder. To view a copy of this licence, visit http://creativecommons.org/licenses/by/4.0/ The Creative Commons Public Domain Dedication waiver (http://creativecommons.org/publicdomain/zero/1.0/) applies to the data made available in this article, unless otherwise stated in a credit line to the data. 


\section{Background}

Noroviruses (NoV) are positive-sense single-stranded RNA viruses and are regarded as one of the main causes of acute gastroenteritis worldwide. Globally, it is estimated that the disease incidence of $\mathrm{NoV}$ has reached approximately $10 \%$ and results in over $\$ 60$ billion in social costs per year [1]. Infection with NoV generally results in abdominal pain, diarrhea, and vomiting [2]. It been noted that NoV infects people of all ages, but is more severe in children and the elderly, especially in low-income countries, leading to over 200,000 deaths every year [3].

Traditional detection methods for NoV, such as immunoassays and electron microscopy, are not suitable for rapid diagnosis because most of them are generally time-consuming and laborious. Common nucleic molecular diagnostic assays for $\mathrm{NoV}$ detection with high specificity and sensitivity, such as fluorescence-based real-time PCR and nested PCR, have been used in disease diagnosis $[4,5]$. However, expensive equipment and the need for trained technicians make these traditional detection methods restrictive and impractical for rapid and convenient detection in low-income regions.

The recombinase-aided amplification (RAA) assay is a new isothermal nucleic acid amplification technology in recent years for pathogen detection. The reaction is typically completed in approximately $30 \mathrm{~min}$ at $37-42^{\circ} \mathrm{C}$. RAA has been successfully applied in the detection of pathogens [6-10] and single nucleotide polymorphisms (SNPs) [11]. Owing to its speed, low-cost, and high sensitivity, RAA is highly suitable for clinical applications, and is a potential assay for the point-of-care testing (POCT) for foodborne pathogens.

In the past two decades, NoV GII.4 has been reported to be the predominant genotype worldwide, and more than half of the outbreaks and sporadic infections are caused by this genotype [12]. For decades, the most popular method for specific detection of NoV GII.4 has been sequencing and phylogenetic analysis [13-15]. Currently, there is no rapid detection method for NoV GII.4. Therefore, it is important to establish an efficient and rapid detection method in response to outbreaks of NoV GII.4. In this work, we describe a novel, isothermal, reverse transcription recombinase-aided amplification (RT-RAA) method for the detection of NoV GII.4.

\section{Methods}

\section{Virus stock and clinical samples}

Positive stool samples of norovirus, enterovirus, astrovirus, adenovirus, sapovirus, and rotavirus used in this study were collected from our previous studies [16]. All samples were diluted to $20 \%(\mathrm{w} / \mathrm{v})$ in phosphatebuffered saline (PBS, pH 7.2), divided into $50 \mu \mathrm{L}$ per tube, and stored at $-80^{\circ} \mathrm{C}$ until use.

\section{Nucleic acid extraction}

Total RNA was extracted from $50 \mu \mathrm{L}$ of each stool sample using the High Pure viral RNA kit (Magen, Guangzhou, China) according to the manufacturer's protocol. The RNA was eluted in $50 \mu \mathrm{L}$ RNase-free water and stored at $-80{ }^{\circ} \mathrm{C}$ until use.

\section{Design of primers and probes}

Complete genome sequences of human norovirus GII.4 strains were obtained from GenBank and used for comparative analyses using MEGA version 7.0 [17]. As the specific site of NoV GII.4 exhibited substantial divergence from other prevalent NoVs (GII.2, GII.3, GII.6, GII.8, and GII.17) and other common foodborne viruses (enterovirus, astrovirus, adenovirus, sapovirus, and rotavirus), it was used as the nucleic target for the RT-RAA of NoV GII.4. The forward and reverse primers and probe were designed according to the manufacturer's guidelines (Qitian, JiangSu, China) (Table 1). All primers and probes were synthesized by Shanghai GENEray (Shanghai, China).

\section{Preparation of viral standards}

The primers F3 and G2SKR were as described in previous studies [18, 19]. A 413-bp (net 4977-5389, GenBank accession no. JX989074) fragment of the ORF1-ORF2 genes of NoV GII.4 was cloned into the pEASY-T1 Vector (Transgen Biotech, Beijing, China) for DNA copy number quantification. Then, the recombinant plasmid was amplified using the Premix Ex Taq Version 2.0 Kit (Takara, Dalian, China) and $2 \mu \mathrm{L}$ template. The nucleotide amplicon was gel purified using the Hipure Gel Pure DNA Mini Kit (Magen) and subjected to in vitro transcription and recovery of RNA using the mMESSAGE mMACHINE $^{\mathrm{sm}}$ T7 Transcription Kit (Thermo Fisher, Shanghai, China) depending on the manufacturer's instructions. The cRNA was quantified using an EPOCH2 Microplate Spectrophotometer (BioTek, Winooski, VT) and the cRNA copy number was calculated using the following formula: cRNA copy number (copy number/ $\mu \mathrm{L})=\left[6.02 \times 10^{23} \times \mathrm{cRNA}\right.$ concentration $(\mathrm{ng} / \mu \mathrm{L}) \times$ $\left.10^{-9}\right] /[$ cRNA length in nucleotides $\times 340]$. The cRNA was aliquoted into centrifuge tubes every $5 \mu \mathrm{L} /$ tube, and stored at $-20^{\circ} \mathrm{C}$ until further use.

\section{RT-qPCR assay}

RT-qPCR reactions were carried out using the One Step PrimeScript $^{\mathrm{s}}$ RT-PCR kit (Perfect Real Time, Takara). Each $20-\mu \mathrm{L}$ reaction mixture contained 4 pmol of forward and reverse primers, $8 \mathrm{pmol}$ of probe, $10 \mu \mathrm{L}$ of $2 \times$ One Step RT-PCR buffer, $2 \mu \mathrm{L}$ of template, $0.4 \mu \mathrm{L}$ of TaKaRa Ex Taq HS, $0.4 \mu \mathrm{L}$ of PrimeScript RT Enzyme Mix II, and RNase Free $\mathrm{dH}_{2} \mathrm{O}$ added to make the volume $20 \mu \mathrm{L}$. The primer pairs were COG2R and QNIF2d 
Table 1 The matching of primers and probes

\begin{tabular}{|c|c|c|c|c|c|c|}
\hline \multirow{2}{*}{$\begin{array}{l}\text { Primer } \\
\text { Name }\end{array}$} & \multirow[t]{2}{*}{ Sequence $\left(5^{\prime} \rightarrow 3^{\prime}\right)$} & \multirow[t]{2}{*}{ Nucleotide } & \multirow[t]{2}{*}{ Length } & \multicolumn{3}{|c|}{ Matching of primer and probe } \\
\hline & & & & $0-2$ bp & $3-4$ bp & $\geq 5 \mathrm{bp}$ \\
\hline RF1 & ATTITACGTGCCCAGACAAGAGCCAATGTTCAG & $4986-5019 /$ & $34 \mathrm{bp}$ & $96.4 \%(53 / 55)$ & $0(0 / 55)$ & $3.6 \%(2 / 55)$ \\
\hline RF2 & CAAGAGCCAATGTTCAGATGGATGAGATTCTCAG & $5003-5036 /$ & $34 \mathrm{bp}$ & $96.4 \%(53 / 55)$ & $0(0 / 55)$ & $3.6 \%(2 / 55)$ \\
\hline RR1 & TCAGATGGGTTGGCGTCACTCGACGCCATCTTC & $5087-5119 /$ & $33 \mathrm{bp}$ & $96.4 \%(53 / 55)$ & $3.6 \%(2 / 55)$ & $0(0 / 55)$ \\
\hline RR2 & GACCCATCAGATGGGTTGGCGTCACTCGACGCC & $5093-5125 /$ & $33 \mathrm{bp}$ & $92.7 \%(51 / 55)$ & $7.3 \%(4 / 55)$ & $0(0 / 55)$ \\
\hline RR3 & TTGGCTGTGGACCCATCAGATGGGTTGGCGTC & $5103-5134 /$ & $32 \mathrm{bp}$ & $96.4 \%(53 / 55)$ & $3.6 \%(2 / 55)$ & $0(0 / 55)$ \\
\hline RR4 & ACGAGGTTGGCTGTGGACCCATCAGATGGGTTGGC & $5106-5140 /$ & $35 \mathrm{bp}$ & $96.4 \%(53 / 55)$ & $3.6 \%(2 / 55)$ & $0(0 / 55)$ \\
\hline RR5 & ACCAGGGGCTTGTACAAAATTGTTTCTAATCCAG & $5234-5267 /$ & $34 \mathrm{bp}$ & $94.5 \%(52 / 55)$ & $5.5 \%(3 / 55)$ & $0(0 / 55)$ \\
\hline RR6 & TTCTAGGGGATACTGTAAACTCTCCACCAG & $5263-5292 /$ & $30 \mathrm{bp}$ & $100 \%(55 / 55)$ & $0(0 / 55)$ & $0(0 / 55)$ \\
\hline RR7 & TGTTCTAATCCAGGGGTCAATTACATTTGT & $5216-5247 /$ & $32 \mathrm{bp}$ & $98.2 \%(54 / 55)$ & $1.8 \%(1 / 55)$ & $0(0 / 55)$ \\
\hline RR8 & AGCCATAACCTCATTGTTGACCTCTGGGACGAG & $5136-5168 /$ & $33 \mathrm{bp}$ & $98.2 \%(54 / 55)$ & $1.8 \%(1 / 55)$ & $0(0 / 55)$ \\
\hline RR9 & TGGCCAAATGGGAAAGGTAGGGGTTCAGATCAG & $5332-5364 /$ & $33 \mathrm{bp}$ & $49.1 \%(27 / 55)$ & $45.4 \%(25 / 55)$ & $5.5 \%(3 / 55)$ \\
\hline RR10 & ATTCTGGCCAAATGAGAAAGGTAGGGATTCAG & $5337-5368 /$ & $32 \mathrm{bp}$ & $47.3 \%(26 / 55)$ & $47.3 \%(26 / 55)$ & $5.5 \%(3 / 5$ \\
\hline RR11 & TATTCACCTGGAGCGTTTCTAGGGGATACTG & $5278-5309 /$ & $32 \mathrm{bp}$ & $96.4 \%(53 / 55)$ & $3.6 \%(2 / 55)$ & $0(0 / 55)$ \\
\hline $\mathrm{ROPa}$ & TCAGACCTGAGCACGTGGGAGGGCGATCGCAAFHQGGCTCCCAGTTTGT & $5033-5082 /$ & $50 \mathrm{bp}$ & $96.4 \%(53 / 55)$ & $3.6 \%(2 / 55)$ & $0(0 / 55)$ \\
\hline
\end{tabular}

${ }^{\mathrm{a}}$ For probe modifications: $\mathrm{F}=\mathrm{dT}-\mathrm{FAM} ; \mathrm{H}=\mathrm{THF} ; \mathrm{Q}=\mathrm{dT}-\mathrm{BHQ}$. The probe has a $3 \mathrm{C}$-spacer for blocking extension

[20]. The size of the amplification product was $89 \mathrm{bp}$. The following amplification conditions were used: $42^{\circ} \mathrm{C}$ for $300 \mathrm{~s}, 95^{\circ} \mathrm{C}$ for $10 \mathrm{~s}$, followed by 45 cycles of $95^{\circ} \mathrm{C}$ for $5 \mathrm{~s}$, and $60^{\circ} \mathrm{C}$ for $20 \mathrm{~s}$.

\section{RT-RAA assay}

RT-RAA reactions were carried out using the modified RAA Kit (Qitian). Each $50-\mu \mathrm{L}$ reaction mixture contained $21 \mathrm{pmol}$ of forward and reverse primers, $6 \mathrm{pmol}$ of probe, $25 \mu \mathrm{L}$ of buffer VI, $2.5 \mu \mathrm{L}$ of template, $1 \mu \mathrm{L}$ of RNase inhibitor $(20 \mathrm{U}), 1 \mu \mathrm{L}$ of RTase $(50 \mathrm{U})$ and nuclease-free water added to make the volume $47.5 \mu \mathrm{L}$. The reaction mixture was added to RT-RAA lyophilized enzyme pellets, and $2.5 \mu \mathrm{L}$ of magnesium acetate was added to the tops of the reaction tube lids. The magnesium acetate droplets were then spun down using a mini centrifuge, and the reactions were quickly transferred to a Lightcycler@96 (Roche, Basel, Switzerland) set to $39^{\circ} \mathrm{C}$ with cycle reads every $30 \mathrm{~s}$. Nuclease-free water was used as a negative control in every test.

\section{Evaluation of specificity and sensitivity}

Enterovirus, astrovirus, adenovirus, sapovirus, and rotavirus were used to evaluate specificity. NoV GII.2, NoV GII.3, NoV GII.6, NoV GII.8, and NoV GII.17 were used to evaluate the specificity of NoV genotypes. The sensitivity of the RT-RAA assay for detection of human NoV GII.4 was identified using 10-fold dilutions of cRNA $\left(10^{7}\right.$ to $10^{0}$ copies per reaction, $\left.n=8\right)$. Negative control reactions were conducted in parallel for each run.
Evaluation of the RT-RAA assay using clinical samples

To evaluate the clinical performance of RT-RAA, a total of 38 clinical samples previously confirmed as NoV GII.4-positive by sequencing assay were used for nucleic acid extraction, and detection in the RT-RAA and RTqPCR assays.

\section{Statistical analysis}

To determine the detection limit of RT-RAA, a probit analysis was performed at a probability level of $95 \%$, and the $p$ and kappa values of RT-RAA and RT-qPCR were calculated. All statistics and analysis were performed by using SPSS 24.0 (IBM Corp, Armonk, NY).

\section{Results}

Development and screening of RT-RAA primer and probe sets

A total of 1942 complete genome sequences of NoVs GII were retrieved from GenBank. Based on bioinformatic analysis, including length, genotype, regional distribution, and prevalence, the non-human NoV strains, repeated sequence strains, obvious long fragment insertion strains, deletion mutations, and long genetic distance strains were removed to obtain 216 reference strains that contained 55 GII.4, 5 GII.1, 20 GII.2, 20 GII.3, 7 GII.5 20 GII.6, 8 GII.7, 1 GII.8, 2 GII.10, 20 GII.12, 6 GII.13, 5 GII.14, 1 GII.16, 20 GII.17, 1 GII.20, 2 GII.21, 3 GII.22, 15 GII.24, and 5 GII.25. Then, the 55 NoVs GII.4 were used as reference strains for comparative analyses to design primers and probes. Twenty-two combinations of candidate primers ( 2 forward and 11 reverse) were produced and screened for reactivity to 
purified GII.4 RNA. Of these, five primer sets were identified as capable of amplifying target RNA, and a probe (ROP) was designed to accommodate all sets (Table 1). All RT-RAA primers were screened by fluorescence RAA and electrophoresis with PCR and RAA. Because of resource constraints, one set of primers (RF1 and RR4 with probe ROP) was chosen for subsequent evaluation. Fifty-five GII.4 sequences were used for alignment with primers RF1, RR4, and probe ROP, and sequence alignment showed that RF1RR4 with ROP was highly conserved for GII.4 (Fig. 1).

\section{Specificity of RT-RAA}

The RT-RAA assay was positive for NoV GII.4 and negative for NoV GI, rotavirus, sapovirus, astrovirus, enterovirus, adenovirus, and the negative control (Fig. 2a). The RT-RAA assay was positive for NoV GII.4, and negative for NoV GII.2, GII.3, GII.6, GII.8, GII.17, and the negative control (Fig. 2b). No cross-reactivity of RNA from any control virus was observed. Therefore, RT-RAA for the detection of NoV GII.4 demonstrates a high specificity for the target.

\section{Sensitivity of RT-RAA}

After serial dilution from $2.67 \times 10^{7}$ to $2.67 \times 10^{0}$ copies/ $\mu \mathrm{L}$, the cRNA of NoV GII.4 was tested using RT-RAA. The results showed that the detection limit of the RTRAA was 3.425 LGC (95\% Cl: 2.906 LGC-4.471 LGC)/ reaction, and the $95 \%$ detection limit of the qRT-PCR was 2.110 LGC (95\% Cl: 1.586 LGC-3.113 LGC)/reaction (Fig. 3; Table 2).

\section{Comparison of the RT-RAA and RT-qPCR assays with clinical samples}

A total of 38 clinical samples were used to evaluate the RT-RAA assay and RT-qPCR. The RT-qPCR showed positive results for 18 out of 38 samples with a positive rate of $47.4 \%$, and RT-RAA showed positive results for 16 out of 38 samples with a positive rate of $42.1 \%$. Compared with RT-qPCR, the kappa value of the RT-RAA assay for NoV GII.4 detection was $0.894(\mathrm{p}<0.001)$, suggesting that both assays were consistent. A detailed comparison of both assays is shown in Table 3 .

\section{Discussion}

In recent years, norovirus outbreaks have gradually increased worldwide. For example, it is estimated that there are 56,000-71,000 hospitalizations and 570-800 deaths due to $\mathrm{NoV}$ infection every year in the United States [21]. The development of diagnostic technology for this virus is of far-reaching practical significance to improve the quality of public health safety. In this study, we set up a rapid, sensitive, and specific RT-RAA assay for the detection of human NoV GII.4.

Established methods for detecting norovirus, such as conventional RT-PCR [22], droplet digital PCR [23], TaqMan-based real-time RT-qPCR [24], recombinase polymerase amplification (RPA) assays [25], and loopmediated isothermal amplification (LAMP) assays [26],

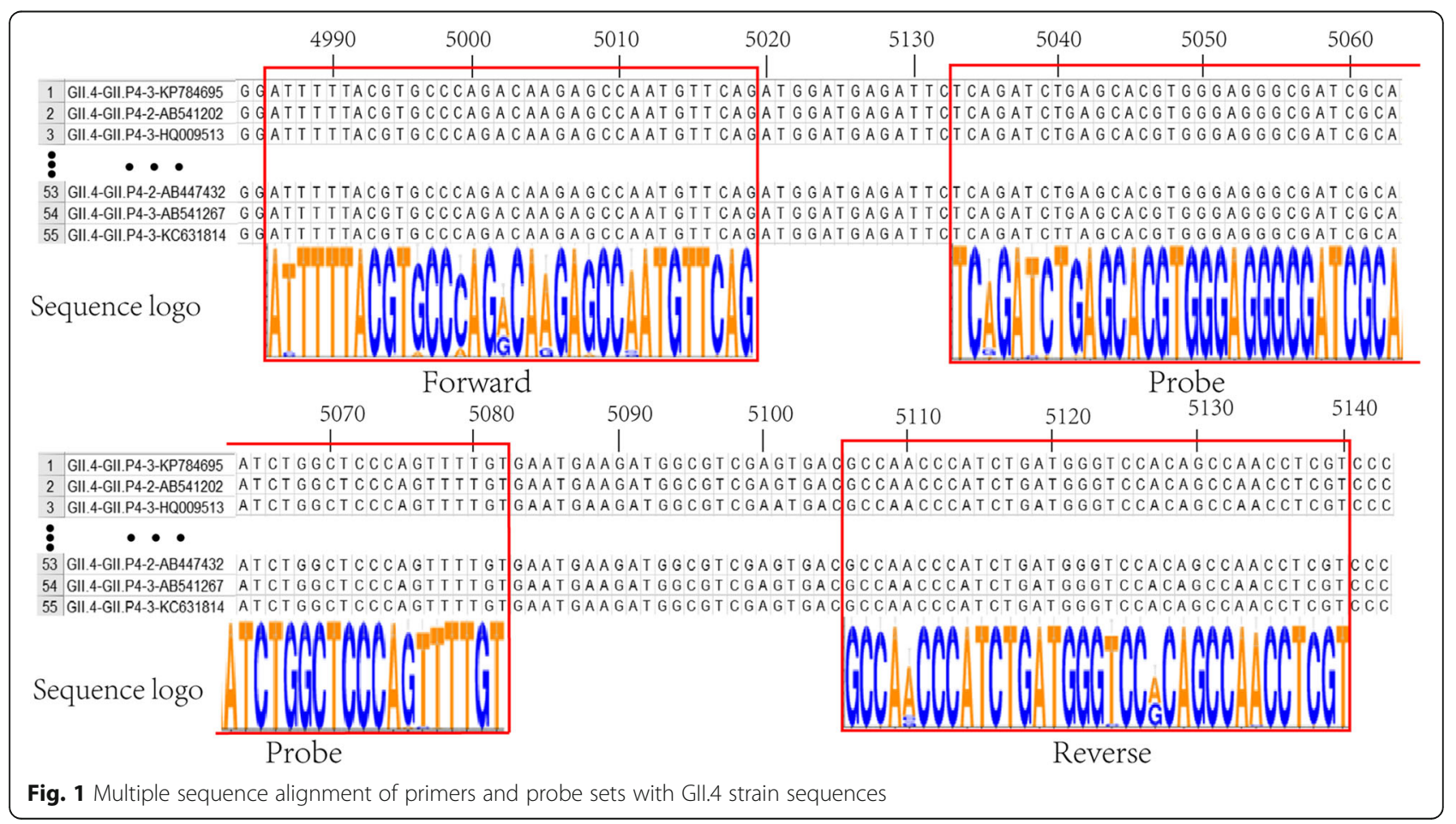




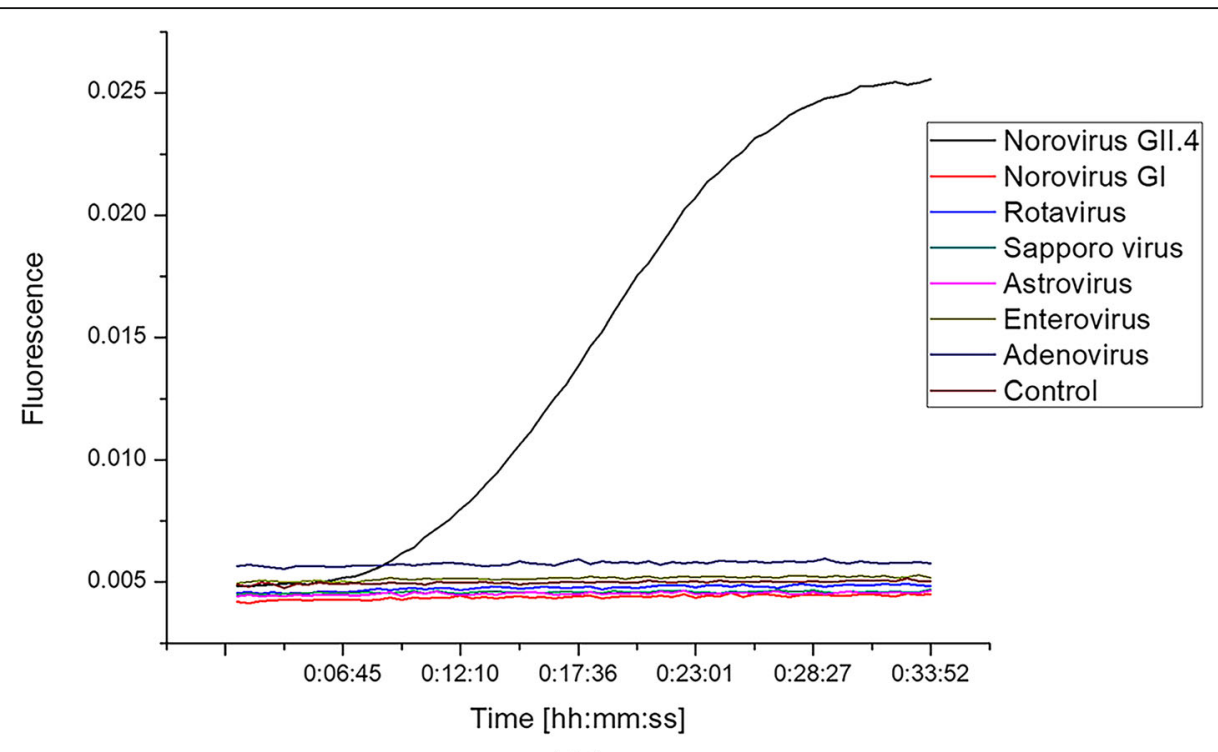

(A)

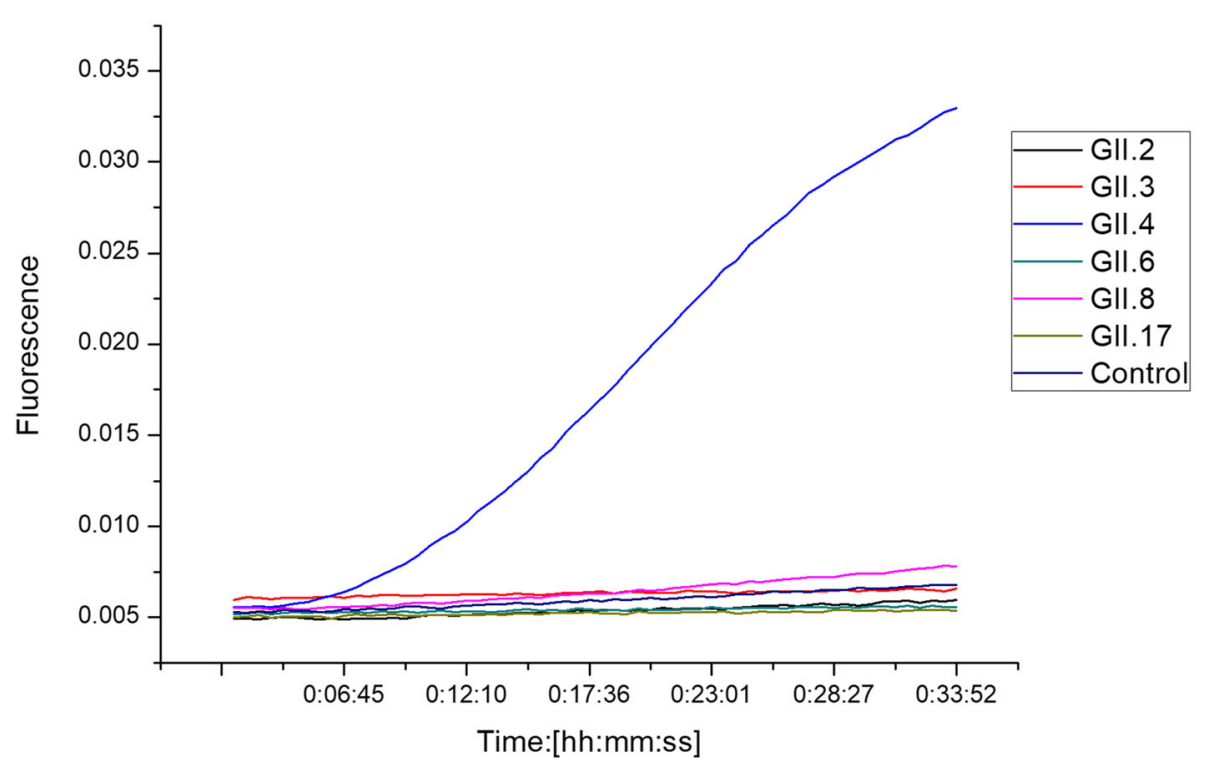

(B)

Fig. 2 Specificity of RT-RAA for NoV GII.4. a The RT-RAA assay was positive for NoV GII.4 and negative for NoV Gl, rotavirus, sapovirus, astrovirus, enterovirus, adenovirus, and the negative control. b The RT-RAA assay was positive for NoV Gll.4, and negative for NoV GIl.2, GIl.3, Gll.6, Gll.8, Gll.17, and the negative control

have multiple limitations. Conventional PCR has limitation of relatively low sensitivity, and requires agarose gel electrophoresis as the final interpretation of the results. TaqMan-based real-time RTPCR requires expensive thermal cycler devices and trained technicians. The assays based on RPA are more expensive than other detection methods, costing approximately $\$ 15$ per reaction. LAMP assays are more sophisticated because at least two pairs of primers need to be designed. Therefore, the development of a fast, cheap, and effective assay to detect norovirus is desirable.

The sensitivity of the newly established RT-RAA assay reached 3.245 LGC per reaction. The kappa values of RT-RAA and RT-qPCR indicated that both assays were highly consistent. The few inconsistencies 


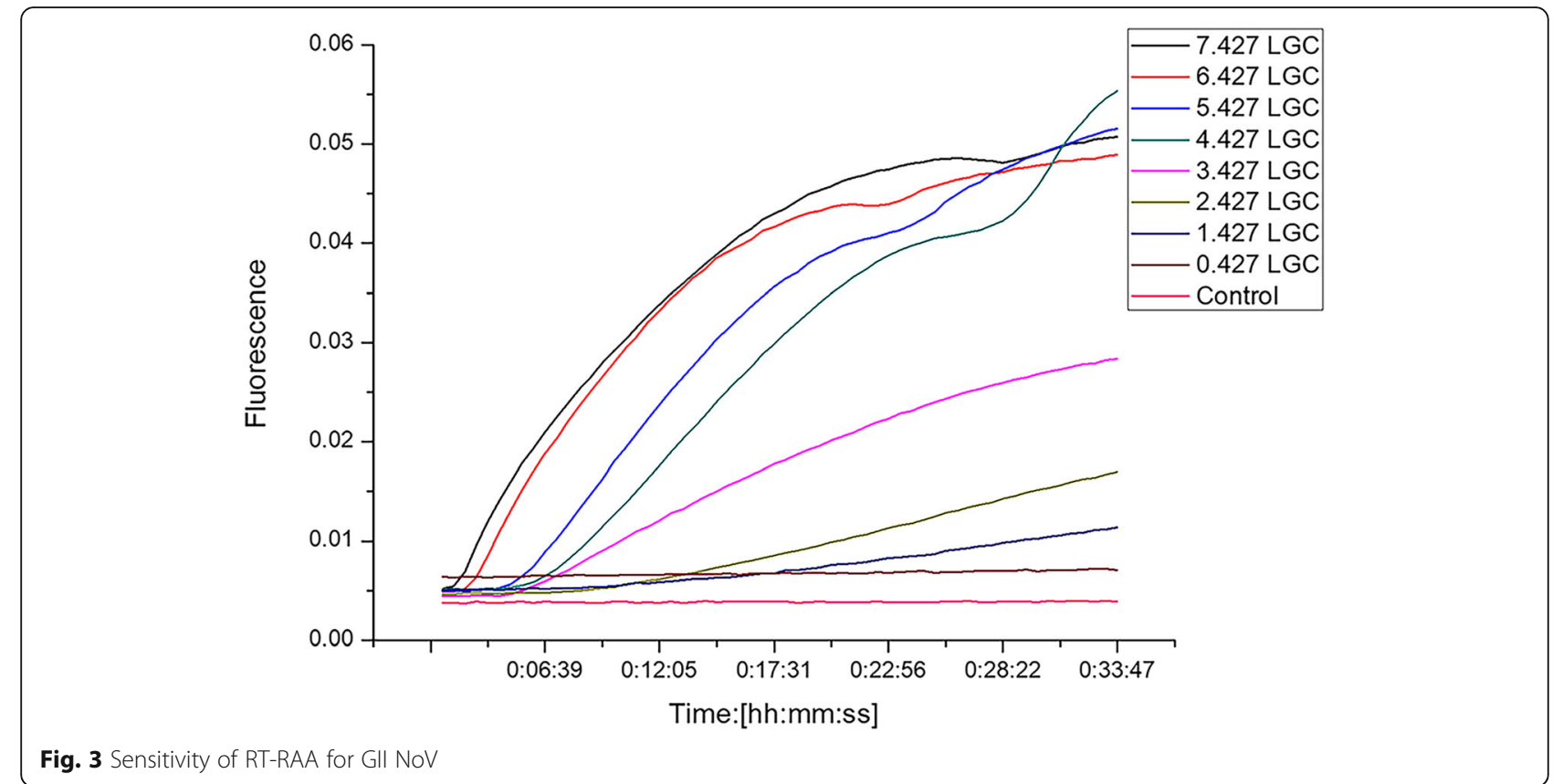

observed might stem from different principles for the two methods and the complexity of clinical samples. Notably, the RT-RAA assay was so rapid that produced positive signal approximately $5 \mathrm{mins}$, and the entire detection protocol could be completed within 30 mins. In contrast, the RT-qPCR and RT-LAMP assays normally require $1.5 \mathrm{~h}$ for completion [27, 28]. Finally, due to thermal cycler limitations, PCR-based detection assays were difficult to integrate in smallscale portable devices amenable for POCT. Compared with LAMP, RT-RAA also effectively avoids the problem of aerosol pollution because the entire assay is completed in the reaction unit without additional opening of the lid. Thus, RT-RAA might be a potential method for POCT of norovirus.
Although the RT-RAA assay has many advantages for detecting foodborne viruses, it also has some limitations. Firstly, it is more difficult to achieve multiplex detection of pathogens using RT-RAA than assays based on PCR because the long primers and probes form dimers more easily [29]. Furthermore, compared with digital PCR, the RT-RAA assay cannot achieve quantitative detection of nucleic acids at current stage. In the future, we will combine the RT-RAA assay with microfluidic digital chip technology for quantitative detection without the need for a thermal cycler or extensive technical expertise, which is expected to become one of the most powerful tools for the rapid and accurate diagnosis of pathogens.

Table 2 Detection limits of human NoVs Gll.4 in RT-qPCR and RT-RAA assays

\begin{tabular}{lll}
\hline $\begin{array}{l}\text { Copies/ } \\
\text { reaction }\end{array}$ & \multicolumn{2}{c}{ Times of positive sample tested by two different assays for NoV $(\boldsymbol{n}=\mathbf{8})$} \\
\cline { 2 - 3 } & RT-qPCR & RT-RAA \\
\hline $2.67 \times 10^{7}$ & 8 & 8 \\
$2.67 \times 10^{6}$ & 8 & 8 \\
$2.67 \times 10^{5}$ & 8 & 8 \\
$2.67 \times 10^{4}$ & 8 & 8 \\
$2.67 \times 10^{3}$ & 8 & 7 \\
$2.67 \times 10^{2}$ & 8 & 6 \\
$2.67 \times 10^{1}$ & 6 & 1 \\
$2.67 \times 10^{0}$ & 2 & 0 \\
\hline
\end{tabular}


Table 3 Clinical performance of RT-RAA for detection of NoV Gll.4

\begin{tabular}{|c|c|c|c|c|c|c|}
\hline \multirow{2}{*}{$\begin{array}{l}\text { RT- } \\
\text { qPCR }\end{array}$} & \multicolumn{2}{|l|}{ RT-RAA } & \multirow[t]{2}{*}{ Total } & \multirow[t]{2}{*}{ Agreement } & \multirow[t]{2}{*}{ Kappa } & \multirow{2}{*}{$\begin{array}{l}p- \\
\text { value } \\
\text { of } \\
\text { kappa }\end{array}$} \\
\hline & Positive & $\overline{\text { Negative }}$ & & & & \\
\hline Positive & 16 & 2 & 18 & $88.9 \%$ & 0.894 & $<0.001$ \\
\hline Negative & 0 & 20 & 20 & & & \\
\hline Total & 16 & 22 & 38 & & & \\
\hline
\end{tabular}

\section{Conclusions}

In conclusion, we successfully established a valuable and alternative RT-RAA analysis for NoV GII.4 detection with low cost, high sensitivity and short time consumption. This new assay can be a suitable method for the diagnosis of $\mathrm{NoV}$ infection in poorly developed areas under restricted conditions.

\section{Abbreviations}

RT-RAA: Reverse transcription recombinase-aided amplification; NoV: Norovirus; LGC: Log10 genomic copies; SNPs: Single nucleotide polymorphisms; POCT: Point-of-care testing; RPA: Recombinase polymerase amplification; LAMP: Loop-mediated isothermal amplification; RTqPCR: Reverse transcription real-time fluorescent quantitative PCR; RTPCR: Reverse transcription PCR

\section{Acknowledgments}

We would like to thank Editage (www.editage.cn) for English language editing.

\section{Authors' contributions}

$\mathrm{YH}, \mathrm{ZQ}, \mathrm{QW}$ and $\mathrm{LX}$ conceived and designed the experiment. ZQ, WC, LX and JG performed the experiments. ZQ WC and LX data statistic analyses. ZQ and $L X$ drafted the manuscript. JY, JZ, YJ, YL, YH and $L W$ revised the manuscript. ZQ, YJ, LX YL, LW, YH and QW reviewed the final manuscript. All authors read and approved the final manuscript.

\section{Funding}

This work was supported by the National Key Research and Development Program of China (2018YFC1602500), the National Natural Science Foundation of China (31872912), the Natural Science Foundations of Guangdong Province for Distinguished Young Scholars (2019B151502065), the Key Research and Development Program of Guangdong Province (2019B020209001), and GDAS'Project of Science and Technology Development (2020GDASYL-20200104008). The funding body had no role in the design of the study and collection, analysis, and interpretation of data and in writing the manuscript.

\section{Availability of data and materials}

The datasets used and/or analysed during the current study are available from the corresponding author on reasonable request.

\section{Declarations}

\section{Ethics approval and consent to participate}

The study was approved by the Research Ethics Committee at the Third Affiliated Hospital of Sun Yat-sen University and the Institutional Review Board (IRB) at the Chinese CDC for the protection of human subjects. The project approval number is 2013(2)-76. After explaining the study objectives in their own local language, which could also help these diarrhea patients to detect norovirus infection free of charge, verbal consent was obtained from all participants or their guardian prior to sample collection. Notably, the samples we used were medical waste which not cause any harm to patients and their information would be kept strictly confidential, and identifiable information would not be disclosed to any members unless patients permission was obtained. Therefore, the procedures for verbal consent were approved by all ethical committees. The verbal consent we documented included the research name, institute, researchers, research background and purpose, benefits and risks of participating in the research, benefits and compensation of subjects, personal information protection and consent statement.

Consent for publication

Not applicable.

\section{Competing interests}

The authors declare that they have no competing interests.

\section{Author details}

${ }^{1}$ Guangdong Provincial Key Laboratory of Microbial Culture Collection and Application, State Key Laboratory of Applied Microbiology Southern China, Institute of Microbiology, Guangdong Academy of Sciences, No. 100, Xianlie Zhong Road, Guangzhou, Guangdong 510070, People's Republic of China. ${ }^{2}$ Faculty Agriculture and Food, Kunming University of Science and Technology, Kunming 650500, Yunnan, China. ${ }^{3}$ Department of Laboratory Medicine, First Affiliated Hospital of Guangzhou Medical University, Guangzhou, Guangdong 510120, People's Republic of China.

Received: 21 October 2020 Accepted: 28 February 2021

Published online: 09 March 2021

References

1. Bartsch SM, Lopman BA, et al. Global economic burden of norovirus gastroenteritis. PLoS One. 2016;11(4):e0151219 https://doi.org/10.1371/ journal.pone.0151219.

2. Moore MD, Goulter RM, et al. Human norovirus as a foodborne pathogen: challenges and developments. Annu Rev Food Sci Technol. 2015;6(1):41133 https://doi.org/10.1146/annurev-food-022814-015643.

3. Bányai K, Estes MK, et al. Viral gastroenteritis. Lancet. 2018;392:175-86. https://doi.org/10.1016/S0140-6736(18)31128-0.

4. Yan $H$, Yagyu F, et al. Detection of norovirus (Gl, GII), sapovirus and astrovirus in fecal samples using reverse transcription single-round multiplex PCR. J Virol Methods. 2003;114(1):37-44 https://doi.org/10.1016/j.jviromet.2 003.08.009.

5. Yoo JE, Lee $\mathrm{C}$, et al. Evaluation of various real-time reverse transcription quantitative PCR assays for norovirus detection. J Microbiol Biotechnol. 2017;27(4):816-24 https://doi.org/10.4014/jmb.1612.12026.

6. Bai $X, M a X$, et al. Field applicable detection of hepatitis B virus using internal controlled duplex recombinase-aided amplification assay and lateral flow dipstick assay. J Med Virol. 2020; https://doi.org/10.1002/jmv.25778.

7. Li Y, Yu Z, et al. Development of a recombinase-aided amplification assay for rapid and sensitive detection of porcine circovirus 3. J Virol Methods. 2020:282:113904.

8. Wang Y, Cui Y, et al. Development of a recombinase-aided amplification assay for detection of orf virus. J Virol Methods. 2020;280:113861 https://doi. org/10.1016/j.jviromet.2020.113861.

9. Xue G, Li S, et al. Reverse-transcription recombinase-aided amplification assay for rapid detection of the 2019 novel coronavirus (SARS-CoV-2). Anal Chem. 2020a;92(14):9699-705 https://doi.org/0.1021/acs.analchem.0c01032.

10. Xue G, Li S, et al. Use of a rapid recombinase-aided amplification assay for mycoplasma pneumoniae detection. BMC Infect Dis. 2020b;20(1) https://doi. org/10.1186/s12879-019-4750-4.

11. Duan S, Li G, et al. A probe directed recombinase amplification assay for detection of MTHFR A1298C polymorphism associated with congenital heart disease. BioTechniques. 2018;64(5):211 https://doi.org/10.2144/btn-201 8-2010.

12. Siebenga JJ, Vennema $\mathrm{H}$, et al. Norovirus illness is a global problem: emergence and spread of norovirus Gll.4 variants, 2001-2007. J Infect Dis. 2009;200(5):802-12 https://doi.org/10.1086/605127.

13. Allen DJ, Trainor E, et al. Early detection of epidemic Gll-4 norovirus strains in UK and Malawi: role of surveillance of sporadic acute gastroenteritis in anticipating global epidemics. PLoS One. 2016;11(4):e0146972 https://doi. org/10.1371/journal.pone.0146972.

14. Nenonen NP, Hannoun C, et al. Norovirus Gll.4 detection in environmental samples from patient rooms during nosocomial outbreaks. J Clin Microbiol. 2014;52(7):2352-8 https://doi.org/10.1128/JCM.00266-14. 
15. Silva LDD, Rodrigues EL, et al. Detection of the pandemic norovirus variant Gll.4 Sydney 2012 in Rio Branco, state of Acre, northern Brazil. Mem Inst Oswaldo Cruz. 2013;108(8):1068-70 https://doi.org/0.1590/0074-0276130293.

16. Xue $L$, Dong $R$, et al. Molecular epidemiology of noroviruses associated with sporadic gastroenteritis in Guangzhou, China, 2013-2015. Arch Virol. 2016; 161(5):1377-84 https://doi.org/10.1007/s00705-016-2784-0.

17. Kumar S, Stecher G, Tamura K. MEGA7: Molecular Evolutionary Genetics Analysis Version 7.0 for Bigger Datasets. Molecular Biology and Evolution. 2016;3(7):1870-4. https://doi.org/10.1093/molbev/msw054.

18. Kojima S, Kageyama T, et al. Genogroup-specific PCR primers for detection of Norwalk-like viruses. J Virol Methods. 2002;100(1-2):107-14 https://doi. org/10.1016/50166-0934(01)00404-9.

19. Luo JWXX. Colorimetric detection of norovirus genotype Gll by reverse transcription loop-mediated isothermal amplification. Chin J Virol. 2012; 28(2):165-71.

20. Loisy F, Atmar RL, et al. Real-time RT-PCR for norovirus screening in shellfish. J Virol Methods. 2005;123(1):1-7 https://doi.org/10.1016/j.jviromet.2020.113 904.

21. Vinjé J. Advances in laboratory methods for detection and typing of norovirus. J Clin Microbiol. 2015;53(2):373-81 https://doi.org/10.1128/JCM.01 535-14.

22. Osazuwa F, Grobler HS, et al. Phylogenetic lineage of Gll.17 norovirus identified among children in south-south, Nigeria. BMC Res Notes. 2020; 13(1) https://doi.org/10.1186/s13104-020-05185-0.

23. Persson S, Eriksson R, et al. Comparison between RT droplet digital PCR and RT real-time PCR for quantification of noroviruses in oysters. Int J Food Microbiol. 2018;284:73-83 https://doi.org/10.1016/j.jffoodmicro.2018.06.022.

24. Gao X, Wang Z, et al. Surveillance of norovirus contamination in commercial fresh/frozen berries from Heilongjiang Province, China, using a TaqMan realtime RT-PCR assay. Food Microbiol. 2019;82:119-26 https://doi.org/10.1016/j. fm.2019.01.017.

25. Moore MD, Jaykus L. Development of a recombinase polymerase amplification assay for detection of epidemic human noroviruses. Sci Rep. 2017;7(1) https://doi.org/10.1038/srep40244.

26. Yaren $\mathrm{O}$, Bradley KM, et al. A norovirus detection architecture based on isothermal amplification and expanded genetic systems. J Virol Methods. 2016;237:64-71 https://doi.org/10.1016/j.jviromet.2016.08.012.

27. Jeon SB, Seo DJ, et al. Development of one-step reverse transcription loopmediated isothermal amplification for norovirus detection in oysters. Food Control. 2017;73:1002-9 https://doi.org/10.1016/j.foodcont.2016.10.005.

28. Zaid Haddadin MDEB. Characteristics of Gll.4 norovirus versus other genotypes in sporadic pediatric infections in Davidson County, Tennessee, USA. Clin Infect Dis. 2020; https://doi.org/10.1093/cid/ciaa1001.

29. Yan $\mathrm{T}$, Li X, et al. Development of a reverse transcription recombinase-aided amplification assay for the detection of coxsackievirus A10 and coxsackievirus A6 RNA. Arch Virol. 2018;163(6):1455-61 https://doi.org/10.1 007/s00705-018-3734-9.

\section{Publisher's Note}

Springer Nature remains neutral with regard to jurisdictional claims in published maps and institutional affiliations.

Ready to submit your research? Choose BMC and benefit from:

- fast, convenient online submission

- thorough peer review by experienced researchers in your field

- rapid publication on acceptance

- support for research data, including large and complex data types

- gold Open Access which fosters wider collaboration and increased citations

- maximum visibility for your research: over $100 \mathrm{M}$ website views per year

At BMC, research is always in progress.

Learn more biomedcentral.com/submissions 